The research program of the Center for Economic Studies (CES) produces a wide range of theoretical and empirical economic analyses that serve to improve the statistical programs of the U.S. Bureau of the Census. Many of these analyses take the form of CES research papers. The papers are intended to make the results of CES research available to economists and other interested parties in order to encourage discussion and obtain suggestions for revision before publication. The papers are unofficial and have not undergone the review accorded official Census Bureau publications. The opinions and conclusions expressed in the papers are those of the authors and do not necessarily represent those of the U.S. Bureau of the Census. Republication in whole or part must be cleared with the authors.

\title{
MICROENTERPRISE AS AN EXIT ROUTE FROM POVERTY:* RECOMMENDATIONS FOR PROGRAMS AND POLICY MAKERS
}

\author{
By \\ Lisa Servon, PhD.** \\ Department of Urban Planning and Policy Development \\ Rutgers University \\ and \\ Timothy Bates, PhD.*** \\ Labor and Urban Affairs \\ Wayne State University
}

CES $98-17 \quad$ November 1998

All papers are screened to ensure that they do not disclose confidential information. Persons who wish to obtain a copy of the paper, submit comments about the paper, or obtain general information about the series should contact sang V. Nguyen, Editor, Discussion Papers, Center for Economic Studies, Washington Plaza II, Room 211, Bureau of the Census, Washington, DC 20233-6101, (301-457-1882) or INTERNET address snguyendinfo. census.gov. 


\begin{abstract}
The objective of this study is to shed light on whether and how microenterprise programs can be used as an economic development strategy to enable low-income people to achieve self-sufficiency through self-employment. Our findings provide little support for the notion that hard work and a small loan are sufficient ingredients for business success. Viable small firms are usually headed by well-educated owners and/or those possessing specific skills that serve as a basis for successful business creation and operation. Potential entrepreneurs lacking assets, skills, and support networks are unlikely to support themselves through self-employment earnings alone. As a poverty alleviation strategy, microenterprise is not a panacea. Nevertheless, programs targeting the poor who do have skills, resources, and support networks can be useful vehicles for helping some to escape poverty.
\end{abstract}

*ACKNOWLEDGMENTS: Research reported in this study was conducted at the U.S. Bureau of the Census, Center for Economic Studies. Findings expressed are those of the authors and do not necessarily reflect the views of the U.S. Bureau of the Census. The assistance of the Woodrow Wilson International Center for Scholars is gratefully acknowledged. Thanks also to the Aspen Institute Non-Profit Sector Research Fund, the U.S. Department of Housing and Urban Development, and the Soroptimist International Founder Region Fellowship for funding portions of this research. Special gratitude goes to the participants, staff, and boards at Women's Initiative, 
Working Capital, and ACCION New York. Sandra Acosta provided excellent research assistance.

\section{Author Biographies}

** Lisa J. Servon is assistant professor in the Department of Urban Planning and Policy Development at Rutgers University and a senior scholar at Rutgers Center for Urban Policy Research. She earned her Ph.D. in the Department of City and Regional Planning at the University of California at Berkeley, with concentrations in the areas of urban economic development and urban poverty policy. Servon has conducted some of the only academic research on microenterprise programs and has published widely on the topic. She is currently completing a book on the microenterprise strategy entitled Credit and the Poor: the Potential and Limits of the Microenterprise Strategy.

***Timothy M. Bates is Distinguished Professor of Labor and Urban Affairs and Professor of Economics at Wayne State University. Bates, who earned his Ph.D. in economics from the University of Wisconsin, has conducted research on self-employment, minority business, and government selfemployment programs for the past 25 years. His most recent book, Race, Self-Employment and Upward Mobility: An Illusive American Dream, was published by Johns Hopkins University Press in 1997. 
Microenterprise programs have received a great deal of attention in the US in recent years as the number and scope of programs have grown. The Aspen Institute's 1996 Directory of U.S.

Microenterprise Programs (Severens \& Kays, 1997) profiled 328 programs in 46 states that assisted in the creation and growth of over 36,211 businesses in 1995 alone, mostly among low-income people. Microenterprise programs provide credit to people who want to be self-employed but who cannot obtain credit through traditional channels. Entrepreneurs who use these programs typically have little or no collateral, problematic credit histories, and nothing but sweat equity to invest in their businesses. Although disadvantaged persons seeking to create or expand small businesses are the target clientele, microenterprise programs themselves vary in the ways they define "disadvantaged" and "small business." Nearly all programs define disadvantaged as people who have difficulty gaining access to credit and training; many further define their target populations by focusing on specific groups. Minorities and women are often the targeted beneficiaries, based upon the belief that discrimination along the lines of race, ethnicity, and gender skews access to business credit and training. The most commonly targeted clients within the larger "difficult access" group, however, are low-income people. Although US microenterprise programs commonly target the poor or near poor, the range of socioeconomic levels that programs serve is rather wide, with $20 \%$ reporting annual incomes below $\$ 6,000$ and $15 \%$ reporting annual incomes above $\$ 30,000$. These income numbers refer to the annual earnings of the respondent only. Household levels are higher, with a median respondent annual household income of $\$ 23,332$. The width of this range indicates that income level is not the only factor impeding access to credit and training. Income level, furthermore, is a tricky indicator of personal disadvantage. Survey data can only provide a snapshot, whereas change over time is much more telling. Does current low income reflect chronic poverty, or has the potential entrepreneur experienced a temporary change in circumstances such as unemployment? We explore alternative measures of economic disadvantaged -- including lack of a high school diploma -- in our analysis of self-employment and small business viability. 
This study focuses on one key claim advocated by a subset of microenterprise proponents -the claim that poor, disadvantaged minority populations can use microenterprise programs as an entry point into the mainstream economy and as a route out of poverty. We have analyzed quantitative data from the US Bureau of the Census, Characteristics of Business Owners (CBO) survey (1991) and qualitative data from interviews with participants in microenterprise programs to examine the characteristics of disadvantaged small business owners and their firms in order to determine which are most likely to succeed. Although evidence suggests that clients of microenterprise programs obtain a range of benefits from participation in these programs, such as increased self-esteem and greater economic literacy (Servon, 1998), we define success more narrowly for the purposes of this research.

We are most interested in understanding the characteristics of businesses and entrepreneurs that lead to economic self-sufficiency. Our examination of these detailed nationwide data suggest that small business ownership is often associated with working poverty. At the same time, self-employment income packaged with other income sources clearly helps to boost the earning power of many lowincome households. For some disadvantaged participants in microenterprise programs, selfemployment is a route to income self-sufficiency. We search for success in self-employment in order to maximize the overlap between these people and program services that meet their needs. One major objective is to determine the self-employment scenarios that are most likely to result in higher earnings. These scenarios are contrasted with types of small businesses that are least likely to provide avenues for bootstrapping oneself out of poverty. 
Our findings provide little support for the popular notion that hard work, frugal living, and a small amount of financial capital are sufficient ingredients for business success. First, young small businesses achieve greater profitability when their owners are well educated, and/or possess specific skills that serve as a basis for business viability. Second, the more profitable young, minority-owned firms compete in the mainstream economy. Catering to minority clients only makes it difficult to achieve business viability. Third, many types of business -- particularly more profitable lines -- require significant capitalization, both financial and human, especially in the first year or two. And fourth, the type of business itself can be an important determinant of success. Traditional lines of business, such as personal services and small-scale retailing, tend to be favored by clients of microenterprise programs, yet these are the least profitable lines of small business. Lacking income, assets, and a strong support network of family, friends, and mentors, the new business owner may simply be unable to survive the lean startup phase of operations.

We argue that microenterprise programs -- particularly those that are credit-led -- should target the subset of the poor who do have the skills, resources, and the support networks that are preconditions for successful small business creation. For those that do not, microenterprise programs must emphasize intensive training programs capable of providing potential business owners with specific skills that can serve as a basis for viable small firm creation and operation. Recent research suggests that mature, well-established microenterprise programs have learned important lessons about screening and providing appropriate training (Servon, forthcoming). Microenterprise programs do add to the financial and human capacity of these firms, but the entrepreneurs need to come to self-employment with a base of skills, support, and determination.

In the next section, we review the definition of critical terms — "disadvantaged" and "small business"- and how these terms have been employed in other studies of microenterprise and by microenterprise programs. In terms of providing guidance about how poor minorities might use microenterprise as a route out of poverty, we find that existing microenterprise program evaluations are deficient. Because the diverse findings of these microenterprise studies are rooted in definitions of terms such as disadvantaged, it is necessary to explore how different definitions lead to different conclusions. 
The section that follows introduces the qualitative and quantitative databases that we use to explore traits of firms and owners that help us to delineate viable from nonviable small businesses. Next, we examine the salient characteristics of small, minority-owned firms formed by disadvantaged owners. We examine gaps between the characteristics of successful self-employed individuals and the firms they operate and the groups targeted by microenterprise programs. The final section sets out policy and program recommendations based on our findings.

\section{DEFINING “SMALL”AND “DISADVANTAGED” IN THE MICROENTERPRISE CONTEXT}

The definition of key terms such as "disadvantaged" and "small business" is critically important to deriving the methodology and interpreting the substantive findings of this study. One can make microenterprises appear to be highly nonviable, rather viable, or somewhere in between by simply altering one's definitions of disadvantaged and small business.

A comprehensive study by Spalter-Roth, Soto, and Zandniapour (1994) questioned the efficacy of relying upon microenterprise as an anti-poverty strategy for women. Their analysis of women nationwide who received some sort of means-tested transfer payments found that 140,332 of them reported self-employment income. This same study found that among employed women, self-employed women were the most likely group to be married to a full-time, full-year working spouse (Spalter-Roth, et al., 1994). Among these self-employed women receiving transfer payments, mean annual hours devoted to self-employment were 605 , and mean self-employment earnings were $\$ 1,948$. On an hourly basis, this translates into $\$ 3.22$ per hour. Most of these women, however, did not rely solely on this source of earned income: Half engaged in self-employment in combination with other wage and salary jobs or a second self-employment job (Spalter-Roth, et al., 1994). Their average hourly earnings from their wage job were $\$ 4.50$, indicating that self-employment yielded less per hour of work than wage employment. This study is based upon a US Bureau of the Census data base known as Survey of Income and Program Participation (SIPP). Earnings calculations were based upon the 1984, 1986, 1987, and 1988 SIPP panels; dollar amounts are stated in 1990 dollars. Note that this study defines 


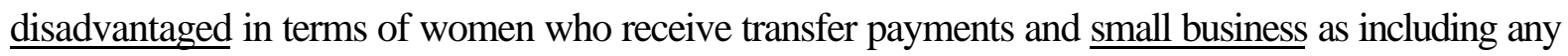
disadvantaged person who reports any amount of self-employment earnings. These specific definitions translate into low self-employment returns and the equation of self-employment among the disadvantaged with working poverty. The question remains whether these women could obtain as much work as they wanted through higher-yielding wage labor. In addition, it is important to recognize that very few microenterprise programs existed during the period in which data were collected, making it unlikely that the women included in this study had participated in microenterprise programs. Therefore, this study is more useful for understanding the role of self-employment in general than the value of training and credit received through microenterprise programs.

In contrast to the findings of Spalter-Roth, et al., Raheim offers a positive analysis of the microenterprise strategy. Raheim (1996) reported on the outcome of the Self-Employment Investment Demonstration (SEID) program, a multi-state micro-enterprise experimental program for AFDC recipients that was implemented in 1986. Raheim concluded that "micro-enterprise development has proven to be a viable approach to creating economic opportunity for many low-income and unemployed Americans" (1996, p.72). Among the businesses created during the SEID program by welfare recipients that were still operating in 1993, Raheim reported that mean firm income in that year was $\$ 21,231$; the median corresponding to that figure, however, was lower and the variation was wide.

Our attempt to reconcile Raheim's findings of microenterprise success with the findings of Spalter-Roth, et al. led us to review the full report on the SEID project (Raheim \& Alter, 1995). We found that Raheim's statement that "the mean income was \$21,231" (1996, p. 78) refers not to microenterprise profits but to their gross sales revenues. Among the welfare recipient entrepreneurs in the SEID project, deducting mean 1993 total business expenses of $\$ 18,220$ from mean gross revenues of $\$ 21,231$ suggests a modest net profit of $\$ 3,011$ for the average microenterprise (Raheim \& Alter, 1995, p. 37). The median microenterprise reported gross sales revenues of $\$ 8,000$ in 1993 , but median expenses and residual firm net income were not reported.

The real profit figure of \$3,011 emerging from Raheim’s study was still over one-third higher than the $\$ 1,948$ amount reported by Spalter-Roth, et al. (1994). Why the difference? Raheim 
studied a survivor group of firms remaining at the end of a time-series analysis. Spalter-Roth, et al. used SIPP cross-sectional data to generate their representative sample of women nationwide who received means-tested welfare payments. The SEID evaluation studied a self-selected and screened group of 120 entrepreneurial welfare recipients, of whom only $2.6 \%$ lacked a high school degree; $20 \%$ were self-employed before they entered the SEID program, and 74.5\% were college-educated. Among the self-employed studied by Spalter-Roth, et al. (1994), nearly $80 \%$ had never attended college. Given the higher profits accruing to the college-educated self-employed (Bates, 1997), the microenterprise profitability figures discussed above are quite compatible across studies.

Data from the Aspen Institute's Self-Employment Learning Project (SELP), a five-year outcome assessment that tracked US microenterprise programs from 1991 through 1996, add greater clarity. SELP analyzed an interview-based sample of 405 of the entrepreneurs served by various programs. Over half of those owning businesses reported that they pieced together income from a business with other employment for wages. Fifty-three percent of the program participants interviewed by SELP sought self-employment because they needed more money or were unemployed. Most were women and/or minorities.

While the microenterprise strategy most commonly targets poor, disadvantaged people interested in starting or expanding a small business, research to date shows that many microenterprise programs are experiencing some difficulty in reaching this group. The SELP study found that the typical microentrepreneur was an educated, skilled worker. Eighty-two \% had a high-school level education or more; $33 \%$ had some college or a technical degree; another $18 \%$ had a college degree, and $6 \%$ completed some post-graduate work (Clark \& Huston, 1993). Finally, nearly half of all respondents owned their homes and most of them reported household incomes well above the poverty line. Although microenterprise programs set out to bring entrepreneurship to the most disadvantaged populations, the portrait that has emerged makes sense, given the demands involved in running a business. Even among the lower income and welfare recipient participants in microenterprise programs, observed education and skill levels are surprisingly high. As a result, the microenterprise field has begun to diversify. Many programs, recognizing that the group they are actually serving differs from the group 
they originally targeted, have decided to focus either on the group that is ready to borrow or on whose who need the most help. 
At any one time, there exists in the US a nontrivial number of college-educated people who are either poor, on welfare, or both. The transitory choices and misfortunes that produce such poverty include bouts of serious unemployment, marriage dissolution, serious accidents and illnesses, and lifestyle decisions to depart from secure employment for a multitude of reasons. In addition, some college education does not always translate into a stable, well-paying job that can sustain a family. Given the fact that this group seems to have trouble gaining access to credit and training through traditional channels, perhaps the realities of today's economy place these non-college graduates into the disadvantaged category. Further, part-time self-employment, packaged with wage income, can be an important boost to household income. Individuals in these categories are often attracted to microenterprise programs. Are they disadvantaged? Once again, the answer depends upon the definition applied.

\section{METHODOLOGY}

This article combines quantitative and qualitative data and analysis in an attempt to obtain a three-dimensional perspective that neither quantitative nor qualitative work alone can achieve. The quantitative analysis provides a more global context of the kinds of small businesses that are most likely to help entrepreneurs to become self-sufficient and the characteristics of disadvantaged entrepreneurs who are most likely to successfully launch successful businesses. The qualitative analysis helps us to understand the specific roles that self-employment in general, and microenterprise programs in particular, play in the lives and economic situations of individual entrepreneurs.

\section{Quantitative Analysis}

Many people generate small amounts of self-employment income, but they are not really running a small business. Because we are seeking to identify traits of viable small firms, our selected definition of what constitutes a firm is intentionally narrow. Our small business data are drawn from the US Bureau of the Census, Characteristics of Business Owners (CBO) database: Only those firms 
generating annual gross sales revenues of $\$ 5,000$ or more are included, and this restrictive definition underlies our summary statistics on small business characteristics and owner traits.

We chose to exclude businesses with sales revenues under $\$ 5,000$ for three reasons. First, many people dabble briefly in self-employment, because they are thinking about possibly launching a small business. Reynolds and Miller estimate that roughly one in 30 of all adults active in the US labor force "appear to be involved in a new firm startup at any point in time" (1992, p. 405). Many of these potential firms never emerge from the formative stage because the various barriers to small business viability are too great for the prospective owner to overcome. The potential entrepreneur may realize, for example, that she lacks sufficient financial capital to pursue dreams of small business ownership. Such formative activities that do not actually result in small business formation do, nonetheless, generate small amounts of self-employment revenues. Applying a $\$ 5,000$ revenue cutoff is a way of weeding out self-employment dabblers.

Data from microenterprise programs support our contention that many people test the selfemployment waters and decide not to continue for a variety of reasons. Women's Initiative for Self Employment, a San Francisco-based microenterprise program, recently conducted a survey of all program participants to determine how they progressed after completing the required courses. The respondents who were not currently in business were asked to check the reasons why they were not. (Responses, which are illustrated in Table 1, add up to more than $100 \%$ because respondents were asked to check all applicable factors.)

\section{INSERT TABLE 1 HERE}

Second, many people generate self-employment income even though they have no intention of owning a small business. Sometimes employees, or people seeking wage work, are offered opportunities to work as independent contractors. This is most common with temporary jobs, and the people who fill such jobs technically receive self-employment income instead of wages. Use of a $\$ 5,000$ cutoff, once again, is a way of weeding out those working temporarily as independent contractors who are not running small businesses (Bates, 1990). 
Third, small amounts of self-employment income are often generated by hobbies or leisure-time activities. An amateur painter may sell a piece of artwork; a collector may sell a collectible. These activities comprise a vast gray area, and it is difficult to differentiate the person seriously trying to operate a small business from the dabbler who really does not consider herself self-employed.

If one includes all of the dabblers and independent contractors in one's base population of small businesses, then annual statistics on gross sales and net income from small business (or selfemployment) will exhibit very low median values, high standard deviations, and large gaps between reported median and mean values. No single cutoff can accurately separate all of the casual selfemployment dabblers from the small business owners, and the $\$ 5,000$ gross sales cutoff used in this study is intentionally steep, serving to eliminate, for example, over $50 \%$ of the high-school dropout minorities who filed small business federal income tax returns in 1987. This methodological technique contrasts sharply with the highly inclusive self-employment definition that led Spalter-Roth, et al. (1994) to conclude that annual self-employment earnings average \$1,948 for women receiving meanstested transfer payments. The highly exclusive small business definition that we have applied to the CBO data describing minorities is equivalent to skewing the analysis toward a positive portrayal of these small businesses.

The CBO samples of small businesses analyzed in this study are national samples of all firms that filed small business income-tax returns (as proprietorships, partnerships, or corporations) in 1987. Compiled by the Census Bureau, these firm samples are representative of the small business universe, subject to the $\$ 5,000$ gross revenues cutoff. The CBO data were generated from an underlying survey of 125,000 self-employed persons that was conducted by the Census Bureau in 1991. Minorities, who represented 75,000 of the surveyed individuals, were intentionally very heavily oversampled. More fully described in Nucci (1992) and Bates (1997), the CBO database is, therefore, ideal for analyzing subsets of minority firms. $\mathrm{CBO}$ data are unique in that they describe both the traits of firms and the characteristics of their owners. Other databases describe owner traits or firm traits, but not both (Bates, 1997). 
Some of the small business literature makes a distinction between an entrepreneur and someone who is self-employed. Lichtenstein and Lyons claim that "entrepreneurs are attempting to develop something new [while] people who are self-employed...engage in selling their labor to perform" routine tasks (1996, p.22). Microenterprise programs commonly do not make this distinction and instead focus on developing the entrepreneurial characteristics of those who are self-employed or wish to be; nor do Census Bureau databases make such distinctions. In this article, we use these terms interchangeably.

\section{Qualitative Analysis}

The qualitative analysis relies on case studies of three microenterprise programs in US inner cities: Women's Initiative for Self Employment (Women's Initiative) in San Francisco/Oakland, which serves low- and moderate-income women; Working Capital in Boston, which targets low-income minority communities but does not target based on any individual characteristics; and Accion New York, which is based in Brooklyn and targets Latinos. While all three programs provide small amounts of credit to microenterpeneurs, the role credit plays within each program's larger mission differs greatly from one program to another. Women's Initiative emphasizes the training component of assisting potential microenterprise owners, and uses loans to assist only a small subset of its clients. Working Capital, in contrast, is overwhelmingly oriented toward making loans and does not offer the formal classes on how to run a small business that are the focus of Women's Initiative. Accion New York differs from Working Capital in that it will not lend to start-ups: All of its loan recipients have been in business for at least a year. Accion offers individual consulting to its business clients, but not the formal classroom instruction that typifies Women's Initiative. Accion New York, Working Capital, and Women's Initiative are broadly representative of the more than 300 microenterprise assistance programs presently operating in the US: These programs vary greatly in their emphasis on lending versus training, and they serve diverse disadvantaged clienteles (Servon, 1997). This study utilizes selected internally generated data describing Women's Initiative, Working Capital, and Accion programs, but our major reliance is upon in-depth interviews with program clients and staff that were conducted by one of the authors. 


\section{TRAITS OF DISADVANTAGED FIRMS AND THE CONTEXT IN WHICH THEY OPERATE}

Poor, disadvantaged Americans, almost by definition, are rarely the ones possessing college degrees, marketable technical skills, or significant personal net worth. Yet, these are the traits most often associated with successful small business creation (Bates, 1997; Gerber, 1995). The SELP and SEID evaluations of microenterprise loan programs discussed earlier in this article revealed that recipients of microenterprise aid are often relatively well-educated and many possess household incomes well above the poverty line. Our in-depth interviews with participants in the Accion, Working Capital, and Women's Initiative programs reveal a similar pattern-- most possess some skill or experience in their line of business. The interview data also reveal two additional characteristics that the quantitative data miss-most microentrepreneurs who are able to achieve self-sufficiency through selfemployment possess a strong support network of family and friends and a fierce determination to succeed. The combination of additional business-related training and access to capital, which microenterprise programs provide, can boost the self-employment activity of entrepreneurs who possess these characteristics.

The success of those entrepreneurs who make it is largely because they possess human and financial capital resources that most poor people lack. A small loan cannot remove the main barrier to successful small business creation, and small amounts of financial capital cannot overcome humancapital deficiencies. This is precisely why the training component of many programs - particularly those that have maintained a commitment to serving the very poor-has grown, while loan funds at many programs remain underutilized.

To develop an understanding of how persons lacking traits commonly associated with successful small business creation are actually doing in the self-employment realm, we selected from the CBO database a subset of firms owned by minorities who fit common disadvantaged stereotypes. We selected only those minority business enterprises (MBEs) whose owners were not high school graduates (described in Table 2). All of these owners started firms between 1979 and 1987 with investments of 
under $\$ 5,000$ in financial capital. Over half of the firms in this small business subset had immigrant owners, many of whom were Hispanic and only a few, Asian. Nearly half (46.9\%) of the firms described in Table 2 were started with no owner investment of financial capital whatsoever. Gross sales in 1987 were typically low, with $61.6 \%$ of the firms generating total revenues of under $\$ 20,000$. Yet, these firms were often vitally important contributors to household income: $46.7 \%$ of the owners reported that earnings from their small businesses were the major source of their household income.

\section{INSERT TABLE TWO HERE}

Table 2 data were derived from the CBO database, and they are representative of the minority subgroup owners nationwide (high school dropout, minimal financial investment) who grossed $\$ 5000$ or more in income and filed small business income tax returns with the Internal Revenue Service in 1987. Overall, according to $\mathrm{CBO}$ data, $31.9 \%$ of all minority-owned businesses nationwide reported gross revenues of under $\$ 5,000$ in 1987 (US Bureau of the Census, 1991).

Low household income was commonplace among this CBO subpopulation of the selfemployed, but it certainly was not universal: $48.8 \%$ reported household incomes from all sources of under $\$ 15,000$. Self-employment is not a high-yielding activity for most: $61.6 \%$ of the firms generated before-tax profits of under $\$ 10,000$ in 1987 . Yet, a significant subset did well, with $9.7 \%$ of the firms netting $\$ 25,000$ and up. What sort of individual, lacking a high school diploma and financial resources, does well in small business ownership? Looking solely at the firms netting $\$ 10,000$ or more before taxes in 1987, a clear-cut profile emerges: The successful person pursuing self-employment in this niche is most commonly a male working in construction.

Persons in construction nationwide, in fact, have the highest self-employment rate (over 22\%) observed in any major industry group in the US (Devine \& Mlaker, 1992). The majority of those employed in construction work in a specific skilled craft, such as carpentry or plumbing, and the skilled craftsperson is most apt to be self-employed. Among those described in Table 2, male immigrant Hispanics in construction were quite common. This pattern is partially rooted in discriminatory barriers limiting women and non-immigrant minority access to training in skilled crafts (Bates \& Howell, 1997; 
Waldinger \& Bailey, 1991). As Table 2 indicates, only $1.3 \%$ of the women-owned firms were in construction, versus $26.4 \%$ of the male-owned firms.

Barriers to acquiring training in the skilled construction crafts that block this route to US-born minorities and women can, on the other hand, provide opportunities to immigrant minorities. Becoming a skilled sheet-metal worker is nearly impossible for minorities growing up in the New York City area (Waldinger \& Bailey, 1991). In Mexico, however, there is no counterpart to the US phenomenon of old-boy networks in construction that minimize access to skill acquisition for persons not connected with the applicable networks, including most minorities. As a result, skilled construction workers who are self-employed are often immigrants, including most Hispanics and over $40 \%$ of blacks self-employed in construction in the New York City area in 1987 (Bates \& Howell, 1997). Possessing a skill such as carpentry is an important form of human capital and supports the notion that one needs appropriate human capital to pursue small business ownership/self-employment successfully.

Every study of "disadvantaged" small business suffers from selection bias because selected parameters have been used to pluck a disadvantaged subset out of a broader small business universe. By focusing solely upon minority-owned businesses grossing revenues of at least $\$ 5,000$ annually, we have attempted to remove the casual self-employed, but we undoubtedly have cast out as well some serious business attempts that were complete flops. The remaining subset of minority firms -- all having owners lacking high school diplomas, and all started with less than \$5,000 capitalization -- has a distinct profile: $79.3 \%$ of the business owners are married and live with their spouse, and $77.9 \%$ of the owners are males. High male representation is partly rooted in high construction representation: $8.8 \%$ of all minority businesses in 1987 were in construction, compared to $22.8 \%$ of the disadvantaged minority firms described in Table 2.

Overall, $38.4 \%$ of these disadvantaged firms generated net profits of $\$ 10,000$ or more in 1987 , and $70.8 \%$ of them were still in business in late 1991 (Table 2). More often than not, the business owners were part of households that had multiple income sources - the presence of other sources acts as a kind of safety net. For over $46 \%$ of the households in which Table 2 firms are embedded, business earnings were the major source of household income. Business earnings appear to boost many of these 
households over the poverty line. Even in cases where business earnings are less than $\$ 10,000$, these earnings, in combination with other household income sources, are vital to lifting the family out of poverty. It is noteworthy, nonetheless, that by themselves most of these businesses generate inadequate earnings to maintain a family of four above the poverty line.

Our overview of disadvantaged businesses owned by minorities reveals gaps between the frequent traits of successful firm owners -- male, married -- and the groups often targeted by microenterprise programs, particularly welfare recipients -- female, often not living with a spouse (Raheim \& Alter, 1995; Spalter-Roth, et al., 1994). Microenterprise programs target these groups in order to provide access to some of the ingredients- - support, training, and capital- -that these groups lack and that impede their ability to start successful businesses. The majority of the businesses described in Table 2 provide supplemental income rather than make their owners self-sufficient. The same is true among firms assisted by microenterprise programs. On one hand, this situation is a positive one -- these businesses' earnings often combine with other income to raise a household above the poverty line. On the other hand, given that the primary focus of this research is self-sufficiency, we must continue to think about ways to increase the ability of these businesses to provide greater support.

The above discussion of minorities self-employed in construction highlights a vitally important aspect of success in small business operation that is often overlooked: Some lines of business consistently offer higher returns to their owners than others. The types of firms started by microenterprise loan recipients are often those that yield much lower returns.

Minority and women-owned businesses traditionally have been heavily concentrated in smallscale retail and personal service firms (often referred to as "traditional" lines of business). Among minority-owned firms operating in these fields, most cater to a minority clientele. Emerging firms include all other fields, particularly businesses that sell to a racially diverse or largely nonminority clientele. Business services, construction, and manufacturing are fields that are most prone to seek customers in the broader economy (Bates, 1993).

Businesses started in microenterprise programs are often traditional. Personal service firms, in particular, have low barriers to entry and are therefore attractive to beginning entrepreneurs. In order to 
understand how the issue of business sectors plays out in a broader context, we returned to CBO data to examine African-American-owned businesses started since 1979. An established body of literature analyses black-owned firms, which facilitates our attempt to identify how disadvantaged businesses fit into this broader small business universe (Bates, 1993).

Table 3 describes a representative nationwide sample of black-owned firms operating in 1987 that had been formed since 1979 (young firms). The sampling criteria resemble those used in the previous section -- all firms grossed $\$ 5,000$ or more and filed a federal small business income tax return -- but no restriction has been imposed regarding owner education or firm capitalization. To facilitate analysis of market potential, black-owned firms are divided into traditional and emerging firm subgroups (Table 3).

\section{INSERT TABLE THREE HERE}

Emerging lines of black enterprise have been the dominant growth areas in the past two decades, and they are, on average, more profitable than traditional lines of black business. Among firms headed by owners who devoted 2,000 or more hours to running the business (full-time owners), traditional and emerging firms reported mean profits of $\$ 13,264$ and $\$ 18,236$, respectively. The traditional/emerging dichotomy is particularly relevant because black women business owners are very heavily overrepresented in the traditional fields: $50 \%$ of the young traditional lines of black enterprise described in Table 3 are women-owned, while men dominate the emerging fields. Gender stereotyping, more than educational credentials, underlies this pattern of business concentration. Among black men lacking high school degrees, the most common type of self-employment is construction (an emerging field active in the mainstream economy), whereas women are most concentrated in the beauty parlor niche (a traditional field reliant upon minority clients). Personal services generally, and beauty parlors specifically, are the least profitable lines of black business enterprise.

Overall, black business owners in the higher yielding, more rapidly growing emerging fields are somewhat more likely to be high school dropouts $(20.1 \%)$ than in the stagnant, lower yielding traditional lines of business (in which $17.5 \%$ of the owners are dropouts). College graduates are certainly much more attracted to the emerging fields (Table 3). Among college-educated, full-time 
owners of black businesses, the emerging group reports profits that are $63.4 \%$ higher than those typifying the traditional firm group. Their heavy overconcentration in low-yielding traditional business fields clearly depresses the self-employment earnings of African-American women.

Ordinary Least Squares (OLS) regression equations explaining the log of the dollar amount of firm pretax profits are presented in Table 4 for the samples of traditional and emerging blackowned firms. The purpose of the regression exercises is to differentiate firm and owner traits associated with higher profits (hence, higher business earnings to support household income) from those linked to lower profits. A secondary purpose is to measure how low firm capitalization, weak educational credentials, and female ownership impact profitability since these traits often represent characteristics of owners (and firms) targeted for assistance by programs aiding disadvantaged businesses. Table 4's OLS regressions analyze the firms described in Table 3, and the explanatory variables are defined in detail in Table 7.

More profitable firms, whether traditional or emerging, are clearly the larger scale operations, and three specific traits typify the larger black-owned businesses. Those owners who work full-time in their businesses, invest substantial financial capital to launch their ventures, and utilize paid employees are the ones running the larger firms and earning the higher profits (Table 4). Furthermore, male owners and those possessing managerial experience prior to self-employment entry generate higher profits than women and persons lacking managerial experience, other factors constant. Two traits are consistently linked to lower profits in Table 4's regression models: operating a firm that has been in operation for no more than two years and catering to a clientele that is predominantly minority. Particularly noteworthy is the finding that traditional and emerging black firms that cater to a minority clientele are significantly less profitable than those competing in the broader, racially diverse economy. Emerging firms in the business services, construction, transportation, manufacturing, and wholesaling fields are most prone to serve a racially diverse or largely nonminority clientele. Interestingly, this breakdown includes two industry groups -- construction and transportation -- in which few of the owners have attended college. Serving a racially diverse clientele is not a firm trait narrowly linked to college-graduate owners. In fact, the regression variables measuring owner education levels exhibited 
much weaker than expected relationships to firm profit levels. Among the traditional black-owned businesses, college graduates, other factors constant, generated profits that were not significantly different from those accruing to high school dropouts. In the emerging business fields, only those owners with post-graduate education were earning significantly higher profits than high school dropouts. Possessing a bachelor's degree is often a route to jobs that provide managerial experience, thus indirectly contributing to higher firm profits. The college graduate trait by itself, however, is a weak determinant of firm profits.

\section{INSERT TABLE FOUR HERE}

Beyond management experience, the other owner trait that is strongly linked to profit levels in traditional lines of business is owner age, a broad proxy for work experience. These patterns suggest that prior work experience is an important way of accumulating the human capital necessary for

successful operation in traditional fields. Together, the owner age and owner age $\mathbf{2}$ variables suggest that the experience that comes with age translates into higher firm profits until the phenomenon of old age (and presumed decline in effort) sets in.

Most of the independent variables used in Table 4 have self-explanatory names, with the exception of the "ongoing" variable. This variable identifies owners who entered self-employment by purchasing a firm that was already in operation (ongoing), as opposed to starting a business from scratch. The findings presented in Table 4 suggest that purchasing an ongoing firm is typically not a shortcut to profitable operation among black-owned businesses.

Overall, Table 4's OLS regressions suggest that business profitability is enhanced by establishing a large-scale, well-capitalized firm that does not rely upon a predominantly minority clientele. Profit prospects are likely to be enhanced, furthermore, if the owner has appropriate human capital for running the envisioned business and devotes herself full-time to the venture. Even the more promising firms, however, should expect to have to endure a start-up phase lasting several years in which newness depresses profits. Newness problems are rooted in learning about one's capabilities as a business owner/operator (Jovanovic, 1982) and building up an established clientele. Being male is clearly linked to enhanced profits. 
The prospective owner lacking appropriate experience and skills in the envisioned business field, lacking financial capital, and targeting a predominantly minority clientele is headed into a business venture that is unlikely to generate much in the way of profits, especially during the early years of operation and especially if the business is a part-time endeavor.

Table 4's OLS regression equations explaining firm profit levels serve as the basis for a complementary set of logistic regression exercises explaining firm discontinuance and survival patterns. These logistic regressions, utilizing the same data and explanatory variables as table four's OLS regression analyses, are conducted primarily to test the robustness of the OLS regression findings on firm profitability. Inherent difficulties plague small business profitability analysis because profits are computed using widely varying accounting conventions regarding depreciation methods, inventory valuation, and so forth. Dollar measures of profitability, therefore, are apt to possess more randomness than the alternative firm viability measure, small business longevity. Furthermore, in the CBO database, nonresponse problems on the initial survey questionnaires were greater for the question regarding owner estimates of before-tax profit amounts than they were for other questionnaire items. The OLS regression equations explaining profits for black-owned firms, nonetheless, produced clear-cut results. However, econometric examination of a second business viability measure -- survival -- may possibly reveal anomalies that call into question the findings from Table 4, or the findings may simply be reaffirmed, albeit from a complementary analysis.

Patterns differentiating traditional from emerging lines of black business are explored by estimating logistic regression equations that explain firm survival (Table 5). The dependent variable in Table 5's logistic regression is whether or not the business operating in 1987 was still functioning in late 1991: Positive coeffiecient values are associated with firms still operating in 1991, and vice versa. Complete explanatory variable definitions are presented in Table 7.

\section{INSERT TABLE FIVE HERE}

Logistic regression results identify strikingly different survival patterns between the traditional and emerging black business groups. Being college educated is strongly, positively associated with firm 
survival among the emerging business owners, but the opposite pattern typifies traditional firms. All of the measures of owner education and experience for traditional firms point toward a common pattern: Greater education and experience predict firm discontinuance. Traditional-firm owners possessing managerial experience prior to self-employment entry are significantly less likely to see their firms survive than other owners; this pattern is absent among the emerging-firm owners.

Human-capital quality does not translate into firm continuity in the traditional black business group. Rather like Asian-immigrant owners (Bates, 1997), ownership of a traditional line of business is positively linked to firm closure for many college-educated African-Americans. The contrast in education variable coefficients (Table 5) reveals a pattern in which well-educated black owners tend to stay in emerging fields and exit from traditional lines of business, other factors constant. Relevant variable coefficients are summarized below:

\begin{tabular}{|l|r|r|}
\hline & Traditional field & Emerging line of business \\
\hline Ed: $1-3$ years college & -.524 & +.504 \\
\hline Ed: college graduate & -.551 & +.424 \\
\hline Ed: graduate school & -.275 & +.642 \\
\hline
\end{tabular}

The financial returns earned by well-educated emerging firm owners appear to be adequate to keep the businesses in operation, while traditional firm owners may be driven by low returns to close their business and face a job search.

Beyond human-capital quality measures, explanatory variables in Table 5's exercises behaved similarly for the traditional and emerging firm groups. The larger scale, better capitalized firms headed by full-time owners were more likely to remain in operation than others. Serving a minority clientele, as opposed to competing in the broader economy, had no significant impact on survival prospects, although traditional firms served the minority niche much more heavily than the emerging lines of blackowned business. Furthermore, self-employment entry via purchasing an ongoing firm did not promote business survival among black owners. Finally, the younger firms were much more likely than the older, established firms to discontinue operations by 1991. 
The failure of traditional black business fields to retain well-educated owners bodes poorly for the future development of this firm group. Is there really no systematic payoff to college education in traditional fields? Table 4's findings indeed indicate that there is not: Higher levels of owner education have no systematic relationship whatsoever to the profitability of traditional black-owned businesses.

The findings of the regression analyses summarized in Tables 4 and 5 clearly indicate that undercapitalization can hurt aspiring entrepreneurs. Microenterprise programs have developed expertise in making very small loans, but many are struggling with how best to serve needy clients. Traditional financial institutions not only avoid making very small business loans, but also shy away from larger business credit needs up to at least $\$ 50,000$. As a result, those entrepreneurs who wish to start businesses requiring greater initial capitalization, as well as those who graduate from microenterprise programs and need to grow into larger loans, often have limited options.

In intensive interviews conducted with borrowers at Women's Initiative for Self Employment, Working Capital, and ACCION New York, some borrowers expressed frustration because of the limits that small loan sizes placed on their growth. Working Capital borrowers must begin borrowing at the $\$ 500$ level and proceed through successive levels regardless of need, credit history, or size of business. A borrower cannot skip a stage or move through the stages more quickly than the designated payment period. Table six illustrates the amounts and terms of each step.

\section{INSERT TABLE SIX HERE}

This process of starting out small and borrowing progressively larger sums of money is called "stepping," and it is being increasingly employed in microenterprise programs, particularly those that use peer lending. At Working Capital, borrowers in peer groups approve each other's loans and base their decisions on whatever criteria the group deems to be appropriate. The primary advantage of employing a stepping method is that small, slow, incremental steps minimize risk. If a borrower defaults, the other members of his or her group are responsible for paying back the loan. This method allows group members to experience borrowing, get to know each other's businesses, and build trust before taking on too much risk. 
The primary disadvantaged of stepping is that it operates to constrain borrowers whose businesses are growing quickly and who need larger amounts of credit in order to keep pace. Manfred, who has moved his rapidly growing graphic design business from his mother's garage to a warehouse space in the year since he joined Working Capital, is experiencing this kind of problem with the stepping process:

The way that their schedule is structured it's just that a company that wants to grow quickly is not going to be able to... It would take me, if I were just to rely just solely on Working Capital for this to be an effective company, to make any sort of profit and be in the black, six years... I think that the lending should coincide with growth. That's like if you can pay back $\$ 500$ in a week, do it, and you've still got that on your credit rating as paying it off.

Manfred has begun to look for other sources of capital to finance the growth of his business, but other sources are scarce.

Kate, who applied for a loan at Women's Initiative after having run her photography lab for a year, believes that her business has been undercapitalized from the beginning. Of the loan she received from Women's Initiative, she says, "I don't think that that loan was enough to support what the plan was. I think you can only have so much expertise as a business consultant, and nobody [at Women's Initiative] knew the photo industry." Other Women's Initiative borrowers discussed the limits that small loan sizes placed on their businesses' growth. Although many microentrepreneurs claim that they are undercapitalized, recent research finds that undercapitalization may be a symptom of owner skill deficiencies (Lichtenstein \& Lyons, 1996).

Recognizing these problems, many microenterprise programs have begun to work cautiously on ways of making larger amounts of capital available to borrowers. Women's Initiative has created some larger loan products. The maximum amount granted to first-time Women's Initiative borrowers is 
$\$ 5,000$. Subsequent loans have run as high as $\$ 20,000$. Women's Initiative currently has four loan products that range in size from $\$ 200$ to $\$ 20,000$. On occasion, Women's Initiative has helped clients who needed more than $\$ 5,000$ to start by working with another organization, such as the San Francisco Mayor's Office on Community Development, to find additional funds. Women's Initiative also helps link borrowers with larger capital needs with area banks with which the program has established relationships.

Working Capital staff also recognize the existence of a market of entrepreneurs who need larger loans and who are not currently being served. Working Capital would like to serve this market and is currently grappling with how best to do so. The most likely scenario would consist first of making larger loans as an extension of what the program already does. In other words, borrowers would still have to proceed through the same levels at the predetermined pace, but the ceiling would be raised to $\$ 10,000$ or more. Program staff are also interested in serving a tier of borrowers who would come in at the $\$ 5,000$ or $\$ 10,000$ level, but all agree that this kind of project would have to be done very cautiously. Upon recognizing that some of its borrowers needed greater financing than Working Capital could provide, staff at the program's Lawrence, Massachusetts-based project worked with seven area banks to develop a spin-off, second-tier microloan program that begins lending at $\$ 5,000$. According to Nelson Quintero, who runs this project, these seven banks

saw the success of Working Capital, how we had developed the program, the number of participants involved, and saw that there was a... gap between $\$ 5,000$ and $\$ 25,000$. Community Development [a City of Lawrence agency] has something called the Small Business Development Loan Fund and that starts at \$5,000 and goes up to $\$ 50,000$. So there was a gap between $\$ 5,000$ and $\$ 25,000$ and that's where the idea of putting this second-tier loan program came from. There were individuals who knew of Working Capital, knew of the Minority Business Council, but at the same time knew that we couldn't meet their needs because they were beyond $\$ 5,000$. 
In addition, the relationships between Working Capital's Lawrence project and the area banks have resulted in learning on the part of the banks. This effort is an important bridge between traditional and alternative financial institutions.

\section{PROGRAM AND POLICY RECOMMENDATIONS}

The microenterprise strategy is not a panacea. When well targeted and clearly focused, however, it can be a critical vehicle for helping some low-income people to achieve economic selfsufficiency. Given that many small businesses are important contributors to household income, how can microenterprise programs target their efforts to increase viability among the assisted firms?

\section{Programs should help qualified entrepreneurs to secure larger loans. Complaints of} undercapitalization and the fact that emerging, more profitable business sectors often require greater capitalization merit recognition from program organizers and policy makers concerned with making self-employment more available to disadvantaged groups. Larger loans must be available to those who have the expertise to use them to build strong businesses.

2. Microenterprise programs should steer entrepreneurs away from narrow, low-income, minority markets. Research shows that entrepreneurs who do business with a narrow, lowincome population become ghettoized and limit their growth and profitability. Business stabilization and growth are more likely when the entrepreneur reaches a broader market. Microenterprise programs must help entrepreneurs to establish firms targeting emerging marketing opportunities.

\section{Microenterprise programs should offer specific training to prepare prospective}

entrepreneurs to enter emerging business areas. In many cases, this kind of training fits with programs' goals of removing discriminatory obstacles. Programs focused on women, for example, could help women to enter such traditional male bastions as the skilled construction trades. A few select programs are beginning to experiment with this kind of focused training. Enabling women to enter more profitable emerging fields that are likely to fully support households is particularly critical given the recent increase in low-income, female-headed households and welfare reform's push to 
move women off welfare and into work. At the same time, microenterprise programs cannot be expected to single-handedly turn disadvantaged people into successful entrepreneurs. Many microenterprise programs — including those studied here- - have begun to network with related organizations and institutions, building skills and providing access to support services such as child care (Servon, 1998).

\section{Programs and policy should focus resources on those entrepreneurs most likely to succeed.}

Many programs already have some system in place to filter out less serious and less prepared entrepreneurs. Often, screening processes involve encouraging those who are not ready for the program to leave it. Some return once they have accumulated the necessary personal resources. Simply using a statistical profile to admit or reject participants will clearly recreate the kind of arbitrary discrimination in which traditional financial institutions have long been involved. At the same time, trying to turn people without the necessary skills into successful entrepreneurs will be costly and lead to program failure. Policy makers seeking to use self-employment as a way to move lowincome people from welfare to work must identify the niche group within the larger group that is, in fact, prepared to consider and succeed at self-employment.

5. The microenterprise strategy needs better evaluation. This study illustrates the need for research on microenterprise programs that uses appropriate control groups. A serious analysis of microenterprise programs as antipoverty programs for welfare recipients, for example, would use the methodological device of the control group. A control group of welfare recipients with the same broad demographic profile and educational credentials as the micro-loan recipients should have been set up at the beginning of the SEID study. Such a comparison group would have been designed to include no micro-loan recipients. When evaluation was undertaken in 1994, it would have been a simple task to compare poverty levels and welfare dependency rates for the micro-loan recipients versus the controls in order to determine the impact of microenterpise involvement upon individual economic status. Microenterprise evaluations to date have never used control groups (see Raheim \& Alter, 1995). It will also be necessary to look at the outcomes these programs produce over the very long term, which will necessitate comprehensive longitudinal studies. 


\section{References}

Bates, T. (1990). "New data bases in the social sciences.” Journal of Human Resources, 25, (4), 625643.

Bates, T. (1993). Banking on black enterprise. Washington, DC: Joint Center for Political and Economic Studies.

Bates, T. (1997). Race, self-employment and upward mobility: An illusive American dream. Baltimore: Johns Hopkins University Press.

Bates, T., \& Howell, D. (1997). The declining status of African American males in the New York City construction market. In P. Mason \& R. Williams (Eds.), Race, markets, and social outcomes, (pp.15-29). (Boston: Kluwer).

Clark, P., \& Huston, T. (1993). Assisting the smallest businesses: Assessing microenterprise development as a strategy for boosting poor communities. Washington, DC: Aspen Institute.

Devine, T., \& Mlaker, J. (1992). Inter-industry variation in the determinants of self-employment. State College: Pennsylvania State University, unpublished report.

Gerber, M. (1995). The e myth revisited. New York: Harper Business.

Jovanovic, B. (1982). "Selection and evolution of industry." Econometrica, 50, (3), 649-670.

Lichtenstein, G. A., \& Lyons, T.S.(1996). Incubating new enterprises: A guide to successful practice. Washington, DC: The Aspen Institute.

Nucci, A. (1992). "The characteristics of business owners data base.” (US Bureau of the Census Center for Economic Studies discussion paper CES92-7).

Raheim, S. (1996). "Microenterprise as an approach to promoting economic development in social work.” International Social Work, 39, (1), 69-82.

Raheim, S., \& Alter, C. (1995). Self-employment investment demonstration: final evaluation report. Washington, DC: Corporation for Enterprise Development.

Reynolds, P., \& Miller, B. (1992). "New firm gestation: Conception, birth, and implications for research." Journal of Business Venturing, 7, (5), 405-417.

Servon, L. (1998). "Credit and social capital: The community development potential of US microenterprise programs." Housing Policy Debate, 9, (1), 115-49.

Servon, L. (1997). "Microenterprise programs in US inner cities: Economic development or social welfare?" Economic Development Quarterly, 11, (2), 166-180. 
Servon, L. (1998). Microenterprise development as an economic adjustment strategy. Report to the Economic Development Administration, US Department of Commerce.

Severens, C., \& Kays, A. (1997). 1996 Directory of U.S. Microenterprise Programs. Washington, DC: The Aspen Institute.

Spalter-Roth, R., Soto, E. and Zandniapour, L. (1994). Microenterprise and women: findings on the viability of self-employment as a strategy for alleviating poverty. Washington, DC: Institute for Women's Policy Research.

U.S. Bureau of the Census, (1991). The Characteristics of Business Owners (Washington, DC: U.S. Government Printing Office.

Waldinger, R., \& Bailey, T. (1991). "The continuing significance of race: Racial conflict and racial discrimination in construction.” Politics and Society, 19, (3), 291-323. 
Table1: Reasons for not being in business

\begin{tabular}{|l|l|}
\hline \multicolumn{1}{|c|}{ Issue } & Response \\
\hline I could not raise enough money & $32 \%$ \\
\hline $\begin{array}{l}\text { I felt that I needed more training relevant to my } \\
\text { business or business idea }\end{array}$ & 24 \\
\hline I wasn't making enough money with my business & 24 \\
\hline $\begin{array}{l}\text { Self-employment requires more time and energy } \\
\text { than I can commit }\end{array}$ & 11 \\
\hline Marketing my product was too difficult & 11 \\
\hline I had an unexpected personal or health event & 11 \\
\hline $\begin{array}{l}\text { I decided my business idea was not as good as I } \\
\text { thought it was }\end{array}$ & 8 \\
\hline I could not produce my product & 5 \\
\hline I found a job & 3 \\
\hline I had too many language difficulties & 3 \\
\hline $\begin{array}{l}\text { I didn't want to give up the benefits I was } \\
\text { receiving from my job }\end{array}$ & 0 \\
\hline Other & 37 \\
\hline
\end{tabular}

Source: WISE Client Follow-up Study, 1993 
Table 2: Traits of Minority-Owned Businesses Nationwide that Started Up with Minimal Human Capital and Financial Capital Investments (firms started after 1979 only)

\begin{tabular}{|c|c|}
\hline 1. Business traits & \\
\hline 1987 gross sales (mean) & $\$ 33,054$ \\
\hline Percent of firms with gross 1987 sales under $\$ 20,000$ & $61.6 \%$ \\
\hline \# employees (mean) & 0.3 \\
\hline Percent of firms with no paid employees & $92.9 \%$ \\
\hline 1987 net profits (mean) & $\$ 11,196$ \\
\hline Percent of firms with net profits in 1987 under $\$ 10,000$ & $61.8 \%$ \\
\hline Total financial capital at startup (mean) & $\$ 1,354$ \\
\hline Percent of firms started with zero financial capital & $46.9 \%$ \\
\hline Percent of firms still in operation, 1991 & $70.8 \%$ \\
\hline 2. Owner traits & \\
\hline Annual owner labor input hours (mean) & $1,664.7$ \\
\hline $\begin{array}{l}\text { Percent reliant upon business for } 50 \% \text { or more of household } \\
\text { income }\end{array}$ & $46.7 \%$ \\
\hline Percent with total household income of under $\$ 15,000$ & $48.8 \%$ \\
\hline Wed, living with spouse & $79.3 \%$ \\
\hline Black & $30.0 \%$ \\
\hline Hispanic & $57.4 \%$ \\
\hline Asian immigrant & $8.4 \%$ \\
\hline All other & $4.2 \%$ \\
\hline Male & $77.9 \%$ \\
\hline 3. Industry groups & \\
\hline Services & $35.5 \%$ \\
\hline Construction & $22.8 \%$ \\
\hline Retail & $16.9 \%$ \\
\hline Transportation & $11.3 \%$ \\
\hline Agriculture services, forestry & $7.4 \%$ \\
\hline Other Industries & $6.1 \%$ \\
\hline
\end{tabular}

Source: Characteristics of Business Owners data base 
Table 3: Small Black-Owned Businesses that Reported Line of Business and were Operating in 1987 (firms started since 1979 only)

$\underline{\text { Business traits }}$

1987 gross sales (mean)

Total financial capital at startup

(mean)

Percent of firms serving

predominately minority clientele

Percent of firms still in operation,

1991

Owner traits

Percent college graduates

Percent with under four years of high

school

Annual owner labor input hours

(mean)

$\underline{\text { Pretax profits } 1987 \text { (mean) }}$

All firms

Firms with owners working full-time

in the business

Firms with college-educated owners

Firms with college-educated owners

working full-time in the business

Source: Characteristics of Business Owners data base $\underline{\text { Traditional }} \quad \underline{\text { Emerging }}$

$\$ 78,290$

$\$ 60,573$

$\$ 17,840$

$\$ 13,048$

$64.5 \%$

$37.7 \%$

$76.9 \%$

$72.7 \%$

$23.4 \%$

$33.2 \%$

$17.5 \%$

$20.1 \%$

1,693

1,846

$\$ 7,846$

$\$ 13,161$

$\$ 13,264$

$\$ 18,236$

$\$ 6,036$

$\$ 13,900$

$\$ 12,866$

$\$ 21,027$ 
Table 4: OLS Regression Explaining Firm Profitability in 1987 Among Black-Owned Business (firms started since 1979 only).

A. Emerging Lines of Business

\begin{tabular}{|c|c|c|c|}
\hline Variable & $\begin{array}{l}\text { Regression } \\
\text { coefficient } \\
\end{array}$ & $\begin{array}{r}\text { Regression coefficient } \\
\text { standard error } \\
\end{array}$ & $\underline{\text { Variable mean }}$ \\
\hline Constant & $8.956^{*}$ & .256 & - \\
\hline Ed: high school & -.029 & .058 & .241 \\
\hline Ed: $1-3$ years college & .024 & .691 & .232 \\
\hline Ed: college graduate & .004 & .065 & .168 \\
\hline Ed: graduate school & $.279 *$ & .064 & .190 \\
\hline Management exper. & $.143 *$ & .043 & .260 \\
\hline Owner age & .003 & .011 & 42.770 \\
\hline Owner age $^{2}$ & .000 & .000 & 1953.0 \\
\hline Male & $.123^{*}$ & .040 & .703 \\
\hline Owner labor input & $.027 *$ & .002 & 18.898 \\
\hline \# employees & $.012 *$ & .003 & .698 \\
\hline Ongoing & .017 & .074 & .064 \\
\hline Wed & .038 & .039 & .698 \\
\hline Capital & $.029 *$ & .005 & 6.020 \\
\hline Leverage & $.008^{*}$ & .004 & 1.529 \\
\hline Minority clientele & $-.163 *$ & .036 & .390 \\
\hline Entered 1984 or 1985 & -.073 & .049 & .230 \\
\hline Entered 1986 & $-.171 *$ & .052 & .195 \\
\hline Entered 1987 & $-.329 *$ & .049 & .268 \\
\hline $\mathrm{n}$ & 2,334 & & \\
\hline $\mathrm{R}^{2}$ & .204 & & \\
\hline $\mathrm{F}$ & 32.9 & & \\
\hline
\end{tabular}




\section{Table 4 (continued)}

B. Traditional Lines of Business

\begin{tabular}{|c|c|c|c|}
\hline Variable & $\begin{array}{r}\text { Regression } \\
\text { coefficient } \\
\end{array}$ & $\begin{array}{r}\text { Regression coefficient } \\
\text { standard error }\end{array}$ & $\underline{\text { Variable mean }}$ \\
\hline Constant & $7.988^{*}$ & .416 & - \\
\hline Ed: high school & .096 & .091 & .353 \\
\hline Ed: $1-3$ years college & -.072 & .096 & .272 \\
\hline Ed: college graduate & -.034 & .111 & .141 \\
\hline Ed: graduate school & .104 & .125 & .084 \\
\hline Management exper. & $.218^{*}$ & .071 & .228 \\
\hline Owner age & .037 & .018 & 44.569 \\
\hline Owner age ${ }^{2}$ & $-.0004 *$ & .0002 & 2107.0 \\
\hline Male & $.108^{*}$ & .059 & .488 \\
\hline Owner labor input & $.023^{*}$ & .003 & 18.484 \\
\hline \# employees & $.011 *$ & .003 & 1.119 \\
\hline Ongoing & $-.190 *$ & .077 & .179 \\
\hline Wed & -.133 & .062 & .674 \\
\hline Capital & $.028^{*}$ & .008 & 6.670 \\
\hline Leverage & .0005 & .005 & 2.112 \\
\hline Minority clientele & $-.150^{*}$ & .057 & .563 \\
\hline Entered 1984 or 1985 & -.078 & .074 & .260 \\
\hline Entered 1986 & $-.177 *$ & .086 & .159 \\
\hline Entered 1987 & $-.279 *$ & .078 & .222 \\
\hline $\mathrm{n}$ & 764 & & \\
\hline $\mathrm{R}^{2}$ & .222 & & \\
\hline $\mathrm{F}$ & 11.8 & & \\
\hline
\end{tabular}

*Statistically significant at the .05 level 
Table 5: Logistic Regression: Explaining Black Firm Survival over the 1987-1991 Period (firms started since 1979 only)

\begin{tabular}{|c|c|c|c|c|}
\hline$\underline{\text { Variable }}$ & $\begin{array}{r}\text { Traditional } \\
\text { Regression } \\
\text { coefficient } \\
\text { (st'd error) }\end{array}$ & 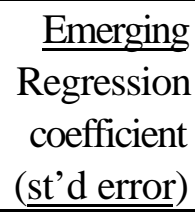 & $\begin{array}{r}\text { Traditional } \\
\text { Variable mean } \\
\end{array}$ & $\begin{array}{r}\text { Emerging } \\
\text { Variable mean } \\
\end{array}$ \\
\hline Constant & $\begin{array}{r}1.364 \\
(.971) \\
\end{array}$ & $\begin{array}{r}-2.666^{*} \\
(.539) \\
\end{array}$ & -- & - \\
\hline Ed: high school & $\begin{array}{l}-.302 \\
(.237)\end{array}$ & $\begin{array}{l}.251 * \\
(.122)\end{array}$ & .328 & .239 \\
\hline $\begin{array}{l}\text { Ed: } 1-3 \text { years } \\
\text { college }\end{array}$ & $\begin{array}{r}-.524 * \\
(.240) \\
\end{array}$ & $\begin{array}{l}.504 * \\
(.128) \\
\end{array}$ & .277 & .242 \\
\hline $\begin{array}{l}\text { Ed: college } \\
\text { graduate }\end{array}$ & $\begin{array}{c}-.551 * \\
(.271) \\
\end{array}$ & $\begin{array}{l}.424 * \\
(.142) \\
\end{array}$ & .137 & .163 \\
\hline $\begin{array}{l}\text { Ed: graduate } \\
\text { school }\end{array}$ & $\begin{array}{r}-.275 \\
(.299) \\
\end{array}$ & $\begin{array}{l}.642 * \\
(.143) \\
\end{array}$ & .102 & .185 \\
\hline $\begin{array}{l}\text { Management } \\
\text { exper. }\end{array}$ & $\begin{array}{r}-.387 * \\
(.172) \\
\end{array}$ & $\begin{array}{r}.017 \\
(.097) \\
\end{array}$ & .218 & .255 \\
\hline Owner age & $\begin{array}{r}.025 \\
(.042) \\
\end{array}$ & $\begin{array}{l}.125^{*} \\
(.024) \\
\end{array}$ & 44.381 & 42.768 \\
\hline Owner age ${ }^{2}$ & $\begin{array}{r}-.0002 \\
(.0005) \\
\end{array}$ & $\begin{array}{r}-.001 * \\
(.0002) \\
\end{array}$ & $2,089.9$ & $1,950.5$ \\
\hline Male & $\begin{array}{r}-.200 \\
(.143) \\
\end{array}$ & $\begin{array}{l}.177^{*} \\
(.088) \\
\end{array}$ & .501 & .715 \\
\hline Owner labor input & $\begin{array}{l}.024 * \\
(.006) \\
\end{array}$ & $\begin{array}{l}.025^{*} \\
(.004) \\
\end{array}$ & 17.193 & 18.762 \\
\hline \# employees & \begin{tabular}{r|}
$.094 *$ \\
$(.047)$ \\
\end{tabular} & $\begin{array}{l}.100 * \\
(.033) \\
\end{array}$ & .975 & .700 \\
\hline Ongoing & $\begin{array}{r}-.259 \\
(.185) \\
\end{array}$ & $\begin{array}{r}.227 \\
(.171) \\
\end{array}$ & .182 & .067 \\
\hline Wed & $\begin{array}{r}.128 \\
(.157) \\
\end{array}$ & $\begin{array}{r}-.027 \\
(.088) \\
\end{array}$ & .704 & .715 \\
\hline Capital & $\begin{array}{r}.059 * \\
(.019) \\
\end{array}$ & $\begin{array}{l}.030 * \\
(.010) \\
\end{array}$ & 6.882 & 6.215 \\
\hline Leverage & $\begin{array}{r}-.015 \\
(.012) \\
\end{array}$ & $\begin{array}{r}.003 \\
(.008) \\
\end{array}$ & 2.540 & 1.737 \\
\hline Minority clientele & $\begin{array}{r}.215 \\
(.140) \\
\end{array}$ & $\begin{array}{r}-.026 \\
(.079) \\
\end{array}$ & .564 & .398 \\
\hline $\begin{array}{l}\text { Entered } 1984 \text { or } \\
1985\end{array}$ & $\begin{array}{r}-1.110 * \\
(.233) \\
\end{array}$ & $\begin{array}{r}-.315^{*} \\
(.118) \\
\end{array}$ & .235 & .222 \\
\hline Entered 1986 & $\begin{array}{r}-1.684 * \\
(.242)\end{array}$ & $\begin{array}{r}-.618^{*} \\
(.119)\end{array}$ & .166 & .195 \\
\hline
\end{tabular}




\begin{tabular}{|c|c|c|c|c|}
\hline \multicolumn{3}{|c|}{ Table 5 (continued) } & \multirow[b]{2}{*}{.291} & \multirow[b]{2}{*}{.290} \\
\hline Entered 1987 & $\begin{array}{r}-1.711^{*} \\
(.217) \\
\end{array}$ & $\begin{array}{r}.792 * \\
(.108) \\
\end{array}$ & & \\
\hline $\mathrm{n}$ & 1,387 & 3,735 & & \\
\hline$-2 \log L$ & $1,307.7$ & $4,035.0$ & & \\
\hline Chi square & 163.1 & 297.5 & & \\
\hline
\end{tabular}

*Statistically significant at the .05 level 
Table 6: Working Capital Stepping Process

\begin{tabular}{|c|c|c|}
\hline STEP & $\begin{array}{c}\text { MAXIMUM } \\
\text { LOAN AMOUNT }\end{array}$ & $\begin{array}{c}\text { TO BE PAID NO } \\
\text { FASTER THAN: }\end{array}$ \\
\hline 1 & $\$ 500$ & $4-6$ months \\
\hline 2 & $\$ 1,000$ & $4-12$ months \\
\hline 3 & $\$ 1,500$ & $4-18$ months \\
\hline 4 & $\$ 3,000$ & $12-36$ months \\
\hline 5 & $\$ 5,000$ & $12-36$ months \\
\hline
\end{tabular}




\section{Table 7: Definitions of Variables Appearing in Econometric Models}

Definitions of the variables used in Table 4's OLS regression models and Table 5's logistic regression models are formally defined below

1. Owner characteristics

a. Education: these variables are defined as equal to one under the following conditions (and defined as zero otherwise):

Ed: high school: those who are high school graduates only

Ed: 1-3 years college: those with some college education

Ed: college graduate: college graduates

Ed: graduate school: those with at least some graduate education

b. Age: to account for possible nonlinearities, the individual's age (owner age) and the squared valued of age (

c. Gender: male is dichotomous variable, set equal to one for males and zero for females.

d. Marital status: wed is dichotomous variable, set equal to one if the individual is married and living with their spouse, zero otherwise.

e. Owner labor input: number of hours during the 1987 calendar year spent by the owner working in the relevant small business, divided by 100 .

f. Management exper: for those working in a managerial capacity prior to owning the business they owned in 1987, management exper $=1$ : otherwise, management exper $=0$.

2. Firm characteristics

a. Capital: the log of the sum of debt and equity capital used to start or become the owner of the business.

b. Leverage: the ratio of debt to equity capital invested in the firm at the point of entry.

c. \# employees: average number of paid workers reported to the federal government on 1987 quarterly payroll forms.

d. Ongoing: if the owner entered a business that was already in operation, ongoing $=1$; if the owner was the original founder of the business, ongoing $=0$.

e. Minority clientele: if 75 percent or more of the firm's customers are minorities, minority clientele $=1$; otherwise 0 . 
f. Entered 1984-1985: if the business was started or ownership was acquired during 1984 or 1985 , then entered $1984-1985=1$; otherwise 0 .

g. Entered 1986: if the business was started or ownership was acquired during 1986, then entered $1986=1$; otherwise 0 .

h. Entered 1987: if the business was started or ownership was acquired during 1987, then entered $1987=1$; otherwise 0 .

\section{Dependent Variables}

In table four, OLS regression models are used to analyze firm profitability. In the OLS regression exercises, the dependent variable is the log of the total dollar amount of firm pretax profits generated in 1987. The distribution of profits among black-owned firms is skewed somewhat by the high-profit subset, and the log transformation of profits solves this problem. Negative profit firms are dropped because of the choice of the log specification. In the table five logistic regression models, the dependent variable is whether or not the business that was operating in 1987 is still functioning in late 1991. Business still operating are considered active firms; those that have closed down are considered discontinued; active firms are represented by a dependent variable of one, while discontinued firms are zero. 